\title{
Article \\ Quantifying Urban Fragmentation under Economic Transition in Shanghai City, China
}

\author{
Heyuan You
}

Received: 8 October 2015; Accepted: 18 December 2015; Published: 25 December 2015

Academic Editor: Tan Yigitcanlar

College of Urban-Rural Planning and Management, Zhejiang University of Finance and Economics, Hangzhou 310018, China; youheyuan@zufe.edu.cn; Tel.: +86-571-8755-7117

\begin{abstract}
Urban fragmentation affects sustainability through multiple impacts on economic, social, and environmental cost. Characterizing the dynamics of urban fragmentation in relation to economic transition should provide implications for sustainability. However, rather few efforts have been made in this issue. Using the case of Shanghai (China), this paper quantifies urban fragmentation in relation to economic transition. In particular, urban fragmentation is quantified by a time-series of remotely sensed images and a set of landscape metrics; and economic transition is described by a set of indicators from three aspects (globalization, decentralization, and marketization). Results show that urban fragmentation presents an increasing linear trend. Multivariate regression identifies positive linear correlation between urban fragmentation and economic transition. More specifically, the relative influence is different for the three components of economic transition. The relative influence of decentralization is stronger than that of globalization and marketization. The joint influences of decentralization and globalization are the strongest for urban fragmentation. The demonstrated methodology can be applicable to other places after making suitable adjustment of the economic transition indicators and fragmentation metrics.
\end{abstract}

Keywords: urbanization; urban fragmentation; economic transition; urban sustainability

\section{Introduction}

Our planet is contemporarily an urbanizing world [1]. A number of megacities, which denote a metropolitan area with a population over 10 million, emerged in Asia [2,3]. However, Asian megacities develop in an uncontrolled manner, posing great threats to urban sustainability [4]. Megacity development typically involves two processes, namely expansion and fragmentation $[5,6]$. Expansion denotes the physical growth of urban land areas. It provides a baseline to describe the magnitude and scope of urban development. Fragmentation refers to the morphological changes (e.g., irregularity and complexity) of urban land patches and their dispersion in space [7]. This concept of fragmentation is proposed on the assumption that the optimum functions of urban systems (e.g., production efficiency and ecosystem protection) are highly correlated with the spatial arrangement of urban land [7]. Urban fragmentation affects sustainability through multiple impacts on economic, social, and environmental cost [8]. Several studies have explored sustainability in relation to urban fragmentation, and they demonstrate that irregularity and dispersion can result in low efficiency of land use $[9,10]$. Urban fragmentation can also decrease the economic returns of land use and therefore lower the incentives for planners [11,12]. In addition, many observations have evidenced that the efficiency of urban land is the key direct drivers of ecosystem service degradation and habitat isolation $[13,14]$. Consequently, the fragmentation process should be investigated in order to provide a comprehensive set of land use indicators to support urban sustainability [7]. 
However, previous studies usually focus on the expansion process and the fragmentation process is largely ignored.

The specific geographical, political and socioeconomic context should be considered in the investigation of urban fragmentation, given that urban development is not uniform in its occurrence [4]. The dramatic economic transition in China provides a unique example to study urban fragmentation [15]. After 1993, the whole nation underwent a fundamental transformation from socialism to a market economy [15]. Local government is granted authority to approve land use by the land market reform [16]. Land subsequently becomes one of the most essential instruments to accumulate wealth and establish public facilities and infrastructures for the local states [17]. Economic restructuring is also enhanced by the globalization, given China's rapid mixing into the world economic system [18]. Driven by these factors, urban land expands in China at an accelerating pace [19]. However, due to the absence of scientific guidance, urban development usually occurs in a disorderly way and presents a fragmented pattern. Recent literature has seen growing efforts in employing remote sensing to characterize urban expansion in the context of China's economic transition [3,20-22]. However, few cases have quantified urban fragmentation in relation to economic transition.

Against the above backdrop, this paper attempts to quantify urban fragmentation in relation to economic transition. Using the case of Shanghai (China), the specific objectives are to: (1) characterize the fragmentation process within Shanghai city across time; (2) analyze the dynamic characteristics of economic transition in Shanghai; and (3) quantify the relationships between urban fragmentation and economic transition.

\section{Materials and Method}

\subsection{Study Area}

The Shanghai city is located is the middle part of the Chinese eastern coast, where the Yangtze River empties into the East China Sea (Figure 1). It borders with the Jiangsu and Zhejiang Province. These three regions constitute the Yangtze Delta Economic Zone, the most developed area in China. It covers about $6300 \mathrm{~km}^{2}$, extending from $30^{\circ} 40^{\prime} \mathrm{N}$ to $31^{\circ} 53^{\prime} \mathrm{N}$ and from $120^{\circ} 52^{\prime} \mathrm{E}$ to $122^{\circ} 12^{\prime} \mathrm{E}$. Shanghai City is the largest one by population in China, and the largest one in terms of urban population proportion ( $89.8 \%$ in 2012) in the world. As the commercial and financial center of China, Shanghai is the fastest urbanizing megacity in China during the last few decades. Its gross domestic product (GDP) saw annual double-digit growth between the 1990s and 2000s. The total population experienced a net growth of approximate 10 million from 1952 and 2012. Besides, the peri-urban areas experienced intensive low-density urban expansion, generating a disorderly and fragmented pattern. Shanghai city provides a useful case to analyze the urban fragmentation in response to economic transition.

\subsection{Data Source and Processing}

Time-series Landsat and CBERS (China-Brazil Earth Resources Satellite) images are used for extracting the urban land information from 1994 to 2013 within Shanghai city. This specific temporal interval is chosen given the start point of market transformation in 1993 and data availability. The images are then visually interpreted by delineating the boundaries of urban land polygons. Visual interpretation is performed because previous studies demonstrate that machine based algorithms are limited to extract accurate information from images of coarse resolution [13-15]. Accuracy assessment is performed by using field survey data and randomly selected points from the original images. The overall accuracy statistics for each year are all higher than $90 \%$. In order to provide an overall view, three years (first, middle, and last) of urban land use maps are shown in Figure 1. 

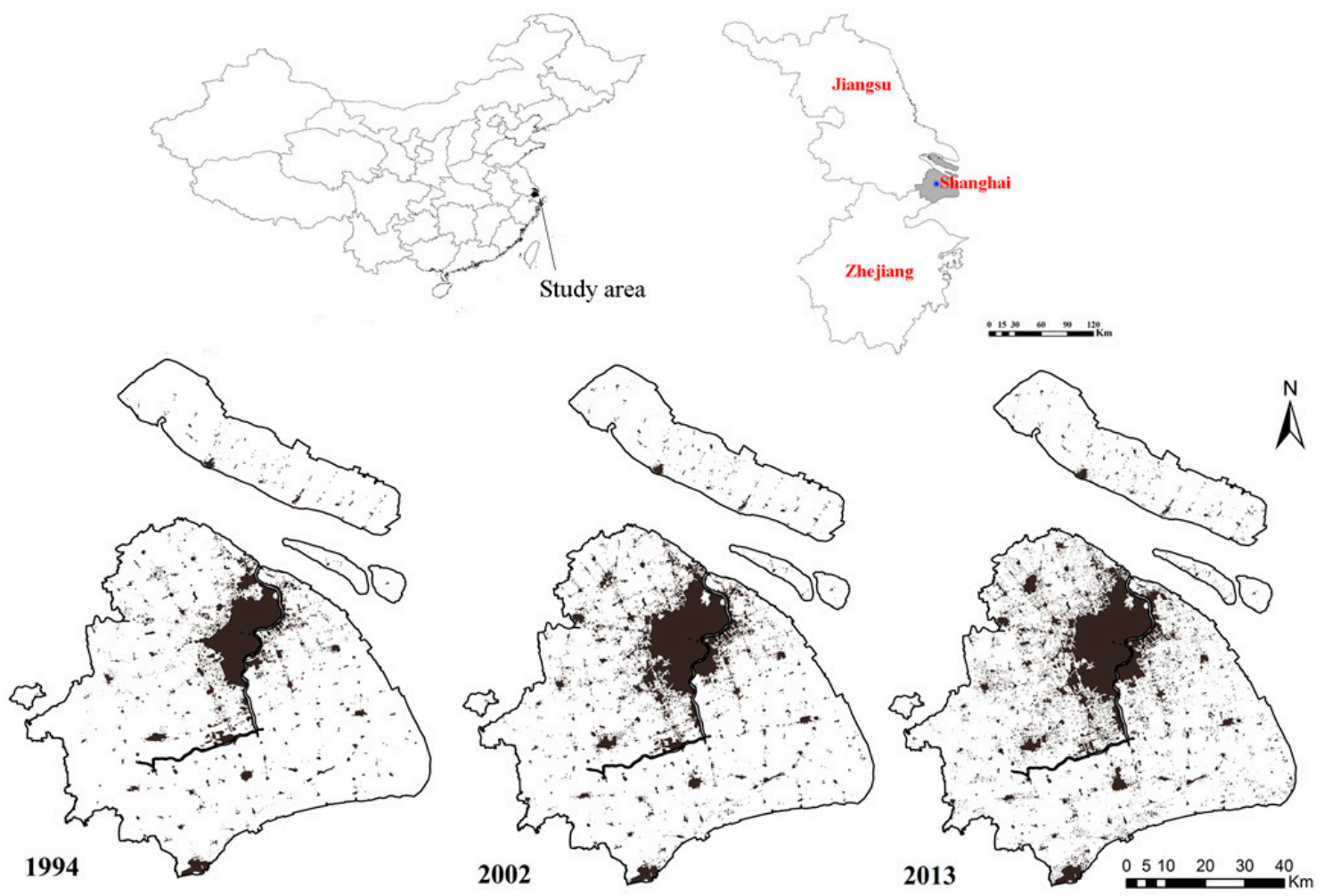

Figure 1. Location of Shanghai (China) and distribution of urban land within it (mapping source: Time-series Landsat imageries) [23].

\subsection{Metric Analysis}

Fragmentation is described by using multidimensional landscape ecological metrics, which typically includes patch size, shape, edge, isolation, and connectivity [24]. However, it is superior to applying a set of metrics rather than employing all metrics, given that metrics always present significant redundancy $[25,26]$. Metric analysis in this study follows the methodology demonstrated in [25]. In brief, metrics are selected based on literature review and then reduced by combining Pearson's correlation analysis, Shapiro-Wilk test, and principal component analysis (PCA). The PCA generates three components and the metrics whose loadings are greater than 0.75 in these three components are kept (Table A1). Five metrics are finally obtained to indicate urban fragmentation, including patch density (PD), edge density (ED), mean Euclidean nearest neighbour distance (ENND), area-weighted shape index (AWSI), and aggregation index (AI). The five metrics describe urban fragmentation from different aspects. As the ratio between urban land patch number and total land area, PD describes the density of urban land and the extent of fragmentation. ED measures the total edge lengths divided by the total land area. ENND measures the average distance between urban land patches. AWSI reflects the shape irregularity of urban land patches. AI measures the frequency of adjacent pairs of urban land patches. Metric calculation is facilitated by the Patch Analyst 4.0 [27].

\subsection{Indicators Selection}

Previous studies indicate that China's economic transition can be described from three aspects: globalization, decentralization, and marketization [20,28-30]. Following the three dimensional framework, I first select 45 indices to indicate economic transition in Shanghai based on literature review and data availability. Pearson's correlation analysis is further applied. If one pair of indices presents high correlation $(|\mathrm{r}| \geqslant 0.75)$, one of them is removed. The final set includes 11 indices 
(Table 1). Data sources include the Shanghai Statistical Yearbook, China City Statistical Yearbook and China Statistical Yearbook. Reasons for selecting these indicators are summarized as follows.

Table 1. Selected indicators of market transition in Shanghai.

\begin{tabular}{|c|c|c|}
\hline Dimension & Variable & Definition \\
\hline \multirow[t]{4}{*}{ Globalization } & Foreign direct investment (FDI) & Total foreign direct investment \\
\hline & Total international trade (TIT) & Total volume of foreign trade \\
\hline & Number of the listed companies (NLC) & Number of listed companies within Shanghai city \\
\hline & Number of oversea companies (NOC) & Number of foreign companies within Shanghai city \\
\hline \multirow[t]{3}{*}{ Decentralization } & $\begin{array}{l}\text { Municipality level financial } \\
\text { decentralization (MLFD) }\end{array}$ & $\begin{array}{l}\text { The ratio of fiscal expenditure per capita at } \\
\text { municipality level to that at national level }\end{array}$ \\
\hline & $\begin{array}{l}\text { Prefectural level financial } \\
\text { decentralization (PLFD) }\end{array}$ & $\begin{array}{l}\text { The ratio of fiscal expenditure per capita at } \\
\text { prefectural level to that at municipality level }\end{array}$ \\
\hline & $\begin{array}{l}\text { Number of national high-tech } \\
\text { development zones (NNHZ) }\end{array}$ & $\begin{array}{l}\text { Number of national high-tech } \\
\text { development zones in Shanghai city }\end{array}$ \\
\hline \multirow[t]{4}{*}{ Marketization } & Private economy proportion (PEP) & $\begin{array}{l}\text { Ratio between private economy } \\
\text { and total gross domestic product }\end{array}$ \\
\hline & Private companies proportion (PFP) & $\begin{array}{l}\text { Ratio between number of private companies } \\
\text { and total number of companies }\end{array}$ \\
\hline & $\begin{array}{l}\text { Economic contribution } \\
\text { of land market (ECLM) }\end{array}$ & $\begin{array}{l}\text { Ratio between land transferring } \\
\text { fees and fiscal revenue }\end{array}$ \\
\hline & Real estate investment proportion (REIP) & $\begin{array}{l}\text { Ratio between investment in real estate } \\
\text { and total investment in fixed assets }\end{array}$ \\
\hline
\end{tabular}

As mentioned above, urban development usually occurs in a disorderly way and presents a fragmented pattern, due to the absence of scientific guidance. We therefore select the indicators that have potential impact on urban development. First, the liberalization of international trade makes Shanghai exposed to global competition [31,32]. Under globalization, Shanghai attracts increasing oversea trade and investment [33]. It would promote urban development since more land is required to establish production bases. We therefore choose three variables to indicate international trade and investment, including foreign direct investment (FDI), total international trade (TIT), and number of oversea companies (NOC). I also choose one more variable (number of listed companies, NLC) to indicate the mixing of local economy with the global economy. Second, decentralization reflects the degree of authority to allocate land resources by the local government. Land is one of the most essential instruments to accumulate wealth and establish public facilities and infrastructures for the local states. Under decentralization, the local government is prone to allocate more land for urban development. We therefore select two variables indicative of financial decentralization at municipality level and prefectural level. Besides, local government always provides preferential terms to attract oversea investment in high-tech development zones. It would definitely promote the allocation of urban land for development. The number of national high-tech development zones (NNHZ) is therefore chosen. Marketization stimulates urban development from two aspects. For one thing, demand for land is increased by the boom of private enterprises and industrialization [30,34]. The variables including private economy proportion (PEP) and private companies proportion (PFP) are therefore selected. For another, supply of land is also increased by the development of urban land market [35]. I therefore choose one more variable: the real estate investment proportion (REIP).

\subsection{Statistical Analysis}

Multivariate linear regression is applied to characterize the relationship between urban fragmentation and economic transition. In particular, metrics are dependent variables, and economic transition indicators are independent variables. All the variables are first subjected to Box-Cox 
normalization transformation and standardization. Then, these variables are entered and removed into the regression model in a stepwise manner, given the problem of multicollinearity. Before regression, a Pearson's correlation is performed to confirm that potential linear relationships exist between urban fragmentation and economic urbanization (Table A2). Also, the traditional variance-in-inflation method is used to identify the multicollinearity among the exploratory variables.

In order to quantify the relative influence of the three components of economic transition (globalization, decentralization, and marketization), we further apply the variance partitioning method, which can decompose the explained variances into fractions for corresponding explanatory factors [21,36]. Specifically, we decompose the total explained variances (adjust $R^{2}$ ) into different fractions: (1) individual contributions of one component; (2) joint contributions of two components; and (3) joint contributions of three components.

\section{Results}

\subsection{Trend of Urban Fragmentation in Shanghai}

Temporal dynamics of urban fragmentation in Shanghai from 1994 to 2013 are exhibited in Figure 2. PD increases linearly from 0.3 to 1.9 , with a net increase of $533 \%$. It denotes that the extent of urban fragmentation is enlarged. ED and AWSI also show an increasing linear trend, denoting that urban land patches become more fragmented and irregular. Conversely, AI presents a declining linear tendency, signifying that urban land patches are more dispersed in space. ENND decreases from 105 to 33 and it shows that the average distance between urban land patches is increased. The trend of these metrics is in line with each other. For example, high density and dispersion co-occur and further shorten the average distance between urban land patches. All these results suggest that urban fragmentation has been intensified in Shanghai during the study period.

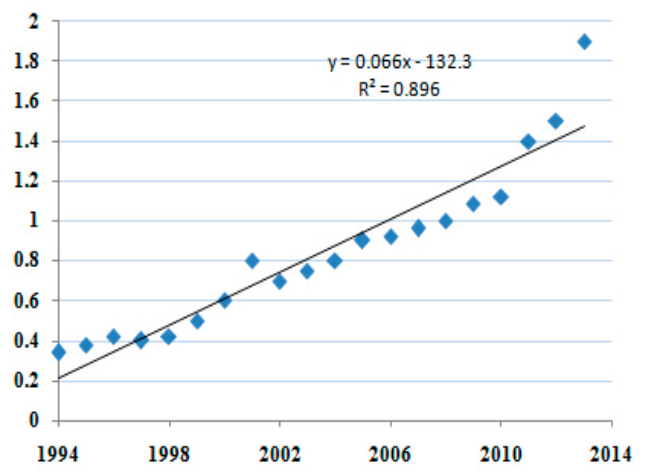

(a)

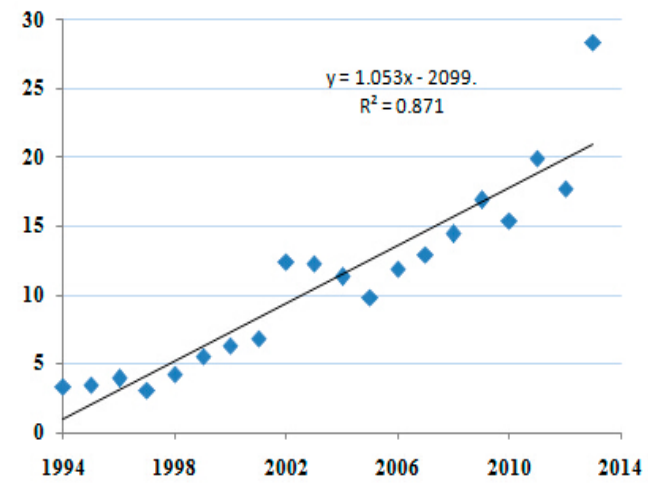

(c)

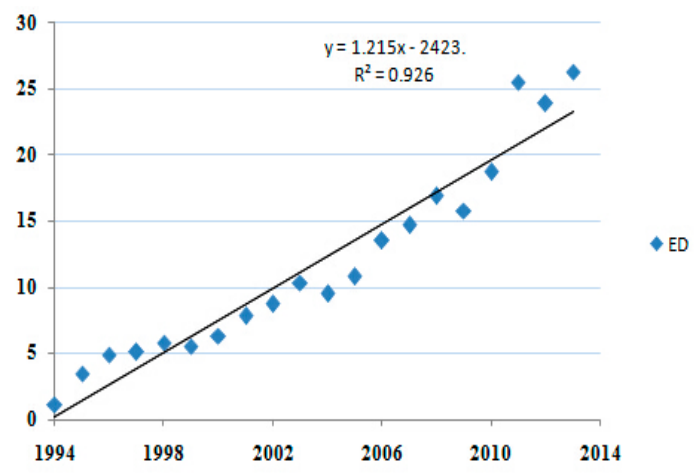

(b)

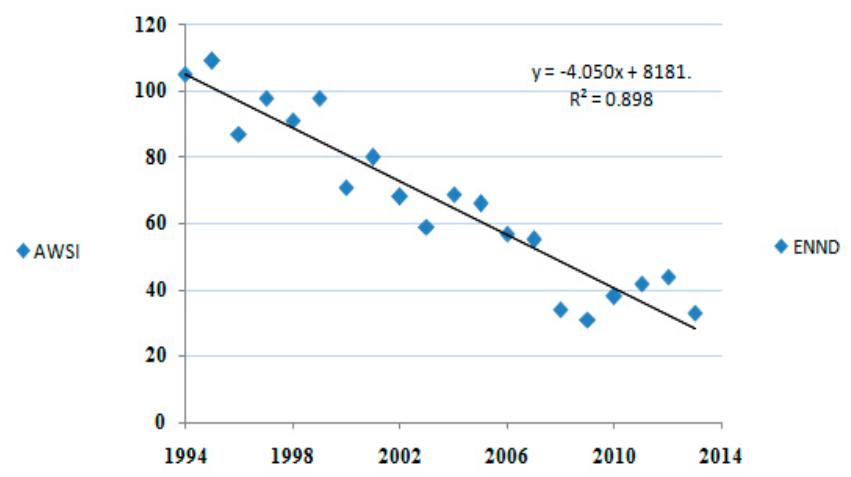

(d)

Figure 2. Cont. 


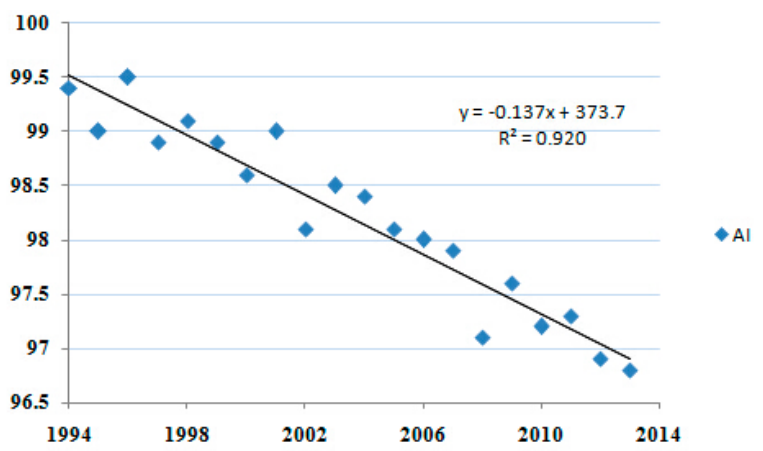

(e)

Figure 2. Temporal trend of urban fragmentation metrics from 1994 to 2013 in Shanghai, China: (a) patch density, PD; (b) edge density, ED; (c) mean Euclidean nearest neighbour distance, ENND; (d) area-weighted shape index, AWSI; (e) aggregation index, AI.

\subsection{Economic Transition Process of Shanghai}

Temporal changes of economic transition indicators in Shanghai from 1994 and 2013 are shown in Figure 3. For indicators of globalization, all the indicators present an increasing exponential trend. It indicates that Shanghai city has attracted more and more oversea investment and engaged actively in international trade. Such a trend also suggests that the local economy has gradually blended into the global economic system and globalization is accelerated during the 20 years. For indicators of decentralization, MLFD and PLFD present a growing trend. It denotes that the local government has obtained more autonomy in allocating land resources. The NNHZ presents similar tendency, which denotes that more land is allocated for developing high-tech industry. For indicators of marketization, RELP presents an increasing linear tendency and the other variables show a growing exponential trend. It signifies that marketable economic system has become prominently bigger and market forces have gradually achieved an essential role in allocating land resources.

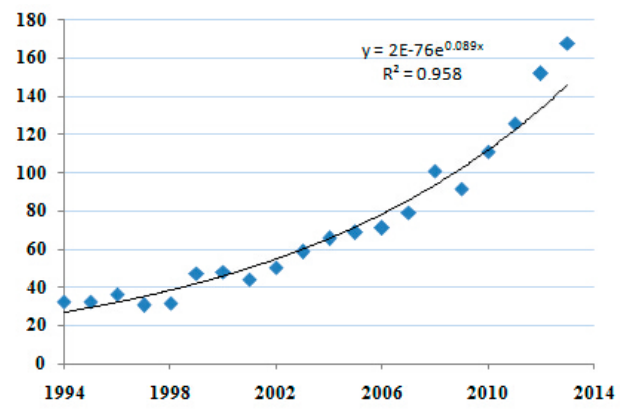

(a)

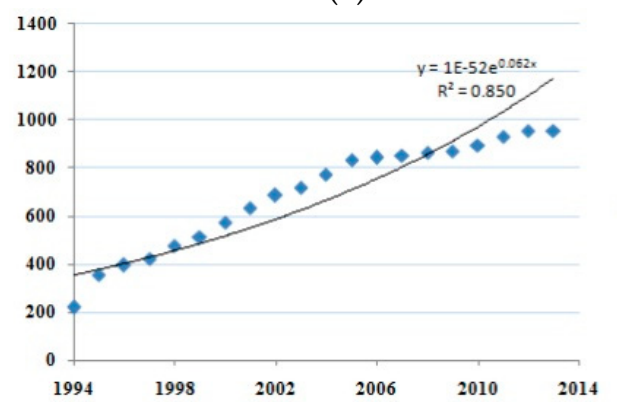

(c)

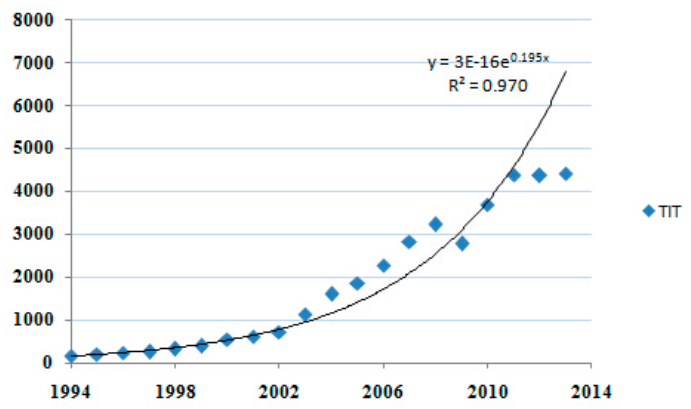

(b)

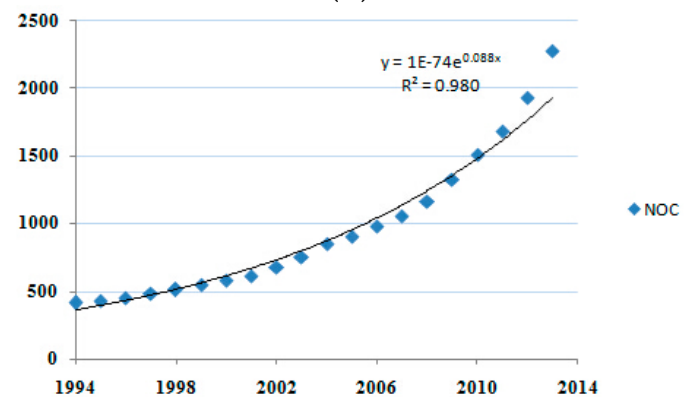

(d)

Figure 3. Cont. 


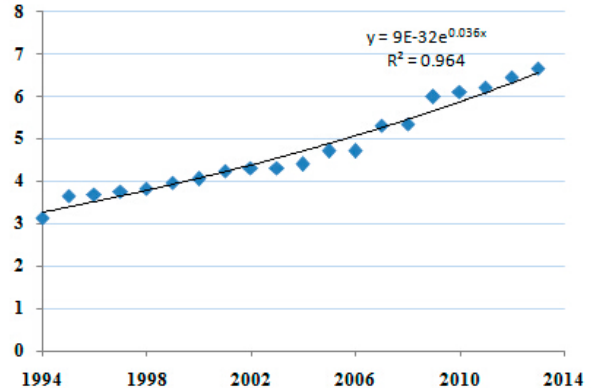

(e)

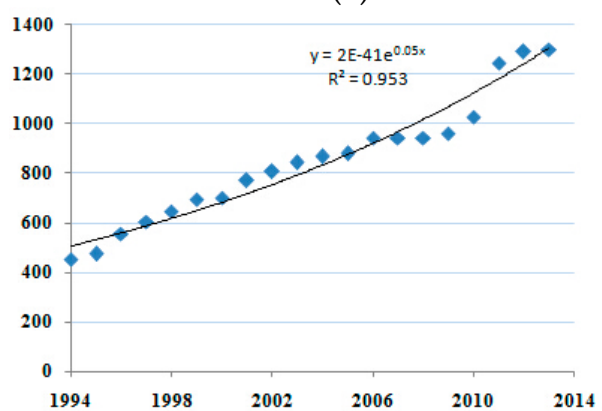

(g)

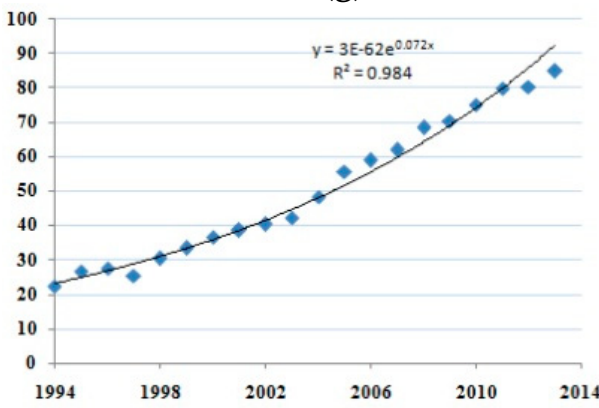

(i)

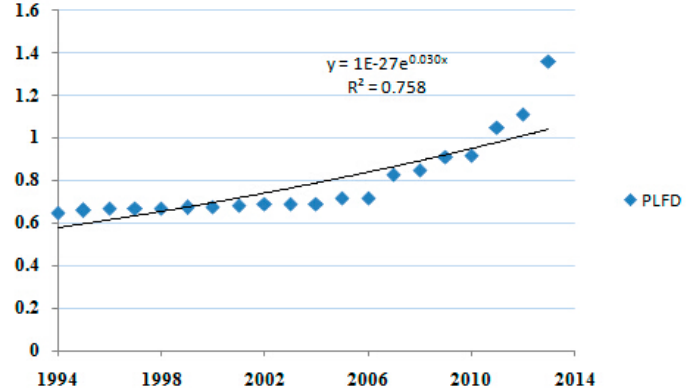

(f)

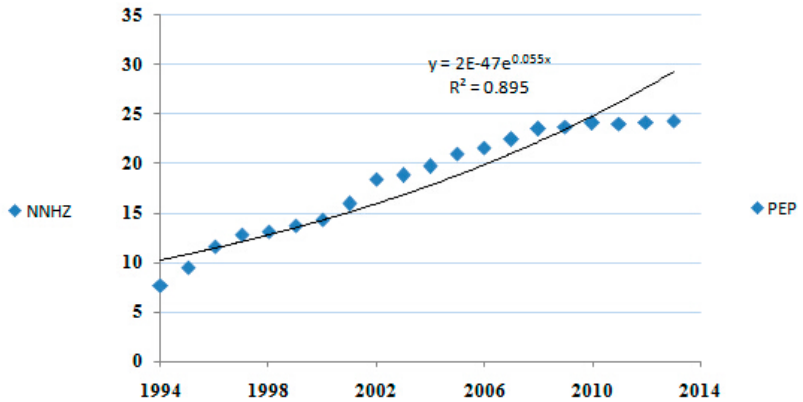

(h)

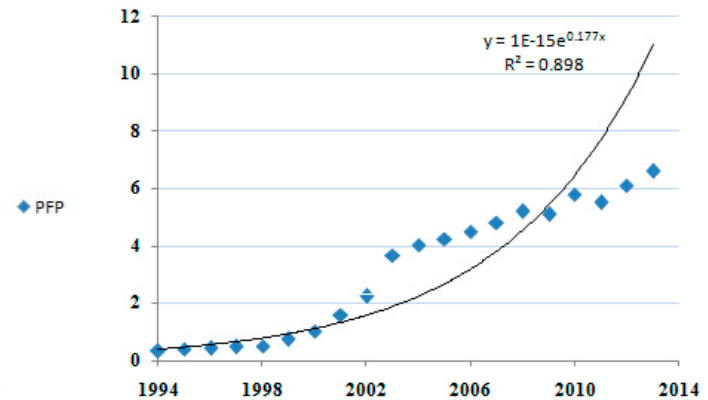

(j)

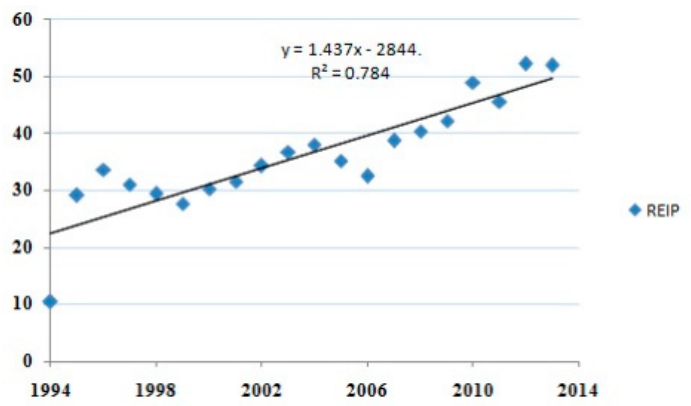

$(\mathbf{k})$

Figure 3. Temporal trend of economic transition indicators from 1994 and 2013 in Shanghai, China: (a) foreign direct investment (FDI; US billion dollar); (b) total international trade (TIT; US billion dollar); (c) number of the listed companies (NLC); (d) number of oversea companies (NOC); (e) municipality level financial decentralization (MLFD); (f) prefectural level financial decentralization (PLFD); (g) number of national high-tech development zones (NNHZ); (h) private economy proportion (PEP; \%); (i) private companies proportion (PFP; \%); (j) economic contribution of land market (ECLM; \%); (k) real estate investment proportion (REIP; \%).

\subsection{Response of Urban Fragmentation to Economic Transition}

Relationships between urban fragmentation and economic transition are shown in Table 2. The regression models are capable of predicting the response of urban fragmentation to economic 
transition, since over $70 \%$ of the total variances are explained. The exploratory economic transition indicators vary with the urban fragmentation metrics. For PD, FDI, PLFD, NNHZ, and ECLM are positive exploratory variables. It denotes that the urban land density is closely correlated with foreign investment, high-tech development zone, prefectural level financial decentralization, and land market. NOC, MLFD, NNHZ, and PEP are positive predictors of ED, and TIT, MLFD and PFP are positive predictors of AWSI. The coefficients denote that instability and irregularity have positive correlations with globalization, decentralization, and marketization. ENND is significantly correlated with NOC, PLFD, REIP, and ECLM. It denotes that the average distance among urban land patches would be decreased when foreign economy, land market, and private economy develop. Through similar analysis, it can be seen that urban land would become more dispersed as international trade and private economy develop. Table 3 shows the relative influence of different components of economic transition on urban fragmentation. It can be seen that the individual influence of decentralization is generally lower than that of globalization and marketization. Besides, the joint influences of decentralization and globalization are the strongest. These results imply that urban fragmentation is more influenced by decentralization and globalization.

Table 2. Relationships between urban fragmentation metrics and economic transition indicators.

\begin{tabular}{|c|c|c|c|}
\hline $\begin{array}{l}\text { Dependent } \\
\text { Variables }\end{array}$ & Exploratory Variables & Regression & Adjust $R^{2}$ \\
\hline PD & FDI, PLFD, NNHZ, ECLM & $\mathrm{Y}=0.145 \times \mathrm{FDI}+0.224 \times \mathrm{PLFD}+0.173 \times \mathrm{NNHZ}+0.089 \times \mathrm{ECLM}$ & $0.71^{* *}$ \\
\hline ED & NOC, MLFD, NNHZ, PEP & $\mathrm{Y}=0.105 \times \mathrm{NOC}+0.187 \times \mathrm{MLFD}+0.133 \times \mathrm{NNHZ}+0.102 \times \mathrm{PEP}$ & $0.61^{* *}$ \\
\hline AWSI & TIT, MLFD, PFP & $\mathrm{Y}=0.185 \times \mathrm{TIT}+0.177 \times \mathrm{MLFD}+0.137 \times \mathrm{PEP}$ & $0.62 * *$ \\
\hline ENND & NOC, PLFD, REIP,ECLM & $\mathrm{Y}=0.113 \times \mathrm{NOC}+0.239 \times \mathrm{PLFD}+0.099 \times \mathrm{REIP}+0.258 \times \mathrm{ECLM}$ & $0.59 * *$ \\
\hline AI & TIT, PLFD, PEIP & $\mathrm{Y}=0.356 \times \mathrm{TIT}+0.245 \times \mathrm{PLFD}+0.146 \times \mathrm{PEIP}$ & $0.55^{* *}$ \\
\hline \multicolumn{4}{|c|}{$\begin{array}{l}\text { ** } p<0.01 \text {. Abbreviations: patch density (PD), edge density (ED), mean Euclidean nearest neighbour distance } \\
(\text { ENND), area-weighted shape index (AWSI), aggregation index (AI), foreign direct investment (FDI), total } \\
\text { international trade (TIT), number of oversea companies (NOC), municipality level financial decentralization } \\
(\mathrm{MLFD}), \text { prefectural level financial decentralization (PLFD), number of national high-tech development zones } \\
(\mathrm{NNHZ),} \mathrm{private} \mathrm{economy} \mathrm{proportion} \mathrm{(PEP),} \mathrm{private} \mathrm{companies} \mathrm{proportion} \mathrm{(PFP),} \mathrm{economic} \mathrm{contribution} \mathrm{of} \\
\text { land market (ECLM), real estate investment proportion (REIP). }\end{array}$} \\
\hline
\end{tabular}

Table 3. Relative influences of different components of economic transition on urban fragmentation (\%).

\begin{tabular}{cccccc}
\hline & PD & ED & AWSI & ENND & AI \\
\hline Globalization & 7.5 & 8.9 & 8.4 & 8.8 & 11.6 \\
Decentralization & 13.3 & 15.6 & 14.2 & 16.4 & 12.7 \\
Marketization & 6.3 & 7.9 & 12.0 & 6.7 & 7.9 \\
Globalization \& Decentralization & 25.1 & 24.1 & 20.4 & 22.2 & 21.5 \\
Globalization \& Marketization & 18.2 & 15.7 & 15.9 & 19.5 & 20.3 \\
Decentralization \& Marketization & 18.1 & 17.7 & 22.2 & 18.1 & 20.1 \\
Globalization \& Decentralization \& Marketization & 11.5 & 10.1 & 6.9 & 8.3 & 5.9 \\
\hline
\end{tabular}

Abbreviations: patch density (PD), edge density (ED), mean Euclidean nearest neighbour distance (ENND), area-weighted shape index (AWSI), aggregation index (AI).

\section{Discussion}

Some fruitful quantitative insights are produced by multivariable regression models, regarding the correlation between urban fragmentation and economic transition. The coefficients for decentralization indicators suggest that urban fragmentation is positively correlated with decentralization. In particular, ED and AWSI are closely related to municipality level decentralization, while PD, ENND, and AI are influenced by prefectural level decentralization. It makes sense in that the local government at a prefectural level is fond of allocating the urban area for real estate development and high-tech development zones in pursuit of more revenue. Municipality level governors pay more attention to the general urban development in the city, but the lack of urban 
form planning in the master land use plan results in the disorderly distribution of urban land, which leads to the increases of irregularity.

Indicators of marketization include two categories: economy and land. Our results show that the two categories of marketization both have significant correlations with urban fragmentation. The identified relationships provide detailed figures to support the hypothesis on public land finance [16]. More specifically, ED and AWSI are subjected to economic marketization, while PD, ENND, and AI are influenced by land marketization. It implies that real estate development is the key contributor to the density and size changes in fragmentation, while industrial development is the critical driver of shape changes in fragmentation. It makes sense because housing land is approved by the master land use plan, while industrial land usually lacks united planning.

Developing countries rely on their abundant resources and cheaper labor to participate in the global competition [37]. A number of oversea companies set up production bases in Shanghai, and the industrial development zones become hotspots of urban development [38]. The problem is that industrial development zones are generally located in suburban areas, and these newly-constructed buildings present a relatively sparse pattern in space [38]. It therefore increases the urban fragmentation. Besides, the local government encourages the local firms to elevate the brand to an international level. Many local firms actively participate in international trade [33]. These local firms, when growing, require more space to enlarge the production base and accommodate the increasing labor. However, the managers usually lose track of the large scale construction in these places, which leads to intensifying urban fragmentation. Therefore, the positive influence of TIT on urban fragmentation should be attributed to the pulling force of international trade and poor regulation.

Comparing the relative influence of the three components of economic transition, we find that decentralization is the most influential factor for urban fragmentation. It makes sense that the development of private and overseas enterprises relies on the support from the local government. We also discover that the joint influences of decentralization and globalization are the strongest. It should be attributed to the fact that the degree of market-orientation and economic openness are heavily determined by the autonomy of the local government.

Wu et al. [39] hypothesize that urban development should experience two stages of diffusion and coalescence. They suggest that a threshold should exist for urban fragmentation with the intensification of anthropogenic activities [40-42]. Our results show that all the metrics exhibit monotonic trend during the 30 years and correlate linearly with economic transition indicators. These results imply that no threshold exists for the dynamic changes of urban fragmentation. The temporal interval only covers 20 years and urbanization may be still in the diffusion phase. The limited temporal scope may contribute to the discrepancy with the hypothesis. Besides, metric calculation is sensitive to spatial extent [40]. The urban fragmentation in Shanghai may be different from that in the study area of [39].

\section{Conclusions}

This paper characterizes the dynamics of urban fragmentation using time-series remotely sensed imageries and a set of landscape metrics. Urban fragmentation presents an increasing linear trend. I also find positive linear response of urban fragmentation to economic transition. More specifically, the relative influence of decentralization is stronger than that of globalization and marketization. The joint influences of decentralization and globalization are the strongest for urban fragmentation. This study demonstrates an analytical framework for quantifying urban fragmentation in response to economic transition. The case of Shanghai reveals that the association between urban fragmentation and economic transition is effectively characterized under the analytical framework. This framework can be applicable to other places after making suitable adjustment of the economic transition indicators and fragmentation metrics. 
It should be underlined that this study only identifies a statistical correlation between economic transition and urban fragmentation. It does not mean that these three economic forces directly promote urban fragmentation. Instead, economic transition just promotes urban development in general and the absence of strict land use planning should be a key mediator. Urban fragmentation would definitely result in the low efficiency of land use since isolated land is considered unsuitable for urban development [42]. It will aggravate the problem of land resource shortage. Fragmented urban land is prone to further fragmentation [42]. Therefore, the intensifying urban fragmentation will decrease the incentives for the rational exploitation of land resources in Shanghai. In order to enhance urban sustainability, Shanghai city should implement a more scientific urban planning to promote a smart growth mode as well as an orderly growth spatial pattern.

Though this study provides quantitative insights into the issue of urban fragmentation, it covers only 20 years of temporal interval. To monitor the ongoing urban fragmentation and evaluate the influence of economic transition, further investigation should be conducted over a longer time span. In addition, the response of urban fragmentation to economic transition is simply quantified by multivariate regression. With enough cities, more reliable estimations of the true relationship between the variables could be obtained. To get a better sense of the casual mechanisms between economic transition and urban fragmentation, it requires the comparison of multiple cities in China and examination of these relationships. In order to obtain deeper knowledge of the complex influential mechanism of economic transition on urban fragmentation, further studies should identify the mediating variables, build structural models, and investigate more cities.

Acknowledgments: This research receives the financial support from theYouth Key Projects of Humanity and Social Science for Universities of Zhejiang Province under Grant No. 2013QN002.

Conflicts of Interest: The author declares no conflict of interest.

\section{Appendix}

Table A1. Components extracted by PCA.

\begin{tabular}{cccc}
\hline & Component 1 & Component 2 & Component 3 \\
\hline AREA_AM & 0.254 & 0.584 & 0.358 \\
PD & 0.854 & 0.203 & 0.449 \\
ED & 0.774 & 0.403 & 0.501 \\
AWSI & 0.304 & 0.796 & 0.607 \\
PARA & 0.349 & 0.712 & 0.308 \\
ENND & -0.228 & -0.556 & -0.811 \\
DIVISION & 0.637 & 0.207 & 0.631 \\
MESH & -0.658 & -0.109 & -0.507 \\
SPLIT & 0.505 & 0.432 & 0.557 \\
IJI & 0.347 & 0.661 & 0.304 \\
AI & -0.138 & -0.802 & -0.701 \\
\hline
\end{tabular}

Table A2. Pearson's correlation analysis between fragmentation metrics and economic transition indicators $\left({ }^{* *} p<0.01\right)$.

\begin{tabular}{cccccccccccc}
\hline & FDI & TIT & NLC & NOC & MLFD & PLFD & NNHZ & PEP & PFP & ECLM & REIP \\
\hline PD & $0.79^{* *}$ & $0.55^{* *}$ & $0.49^{* *}$ & 0.31 & $0.29^{* *}$ & $0.69^{* *}$ & $0.65^{* *}$ & $0.68^{* *}$ & $0.53^{* *}$ & $0.70^{* *}$ & 0.44 \\
ED & $0.26^{* *}$ & $0.38^{* *}$ & 0.25 & $0.81^{* *}$ & $0.62^{* *}$ & $0.46^{* *}$ & $0.74^{* *}$ & $0.57^{* *}$ & $0.67^{* *}$ & 0.49 & 0.24 \\
AWSI & $0.49^{* *}$ & $0.70^{* *}$ & $0.39^{* *}$ & 0.21 & $0.68^{* *}$ & 0.28 & $0.51^{* *}$ & $0.75^{* *}$ & $0.52^{* *}$ & 0.35 & 0.17 \\
ENND & $0.15^{* *}$ & $0.27^{* *}$ & 0.32 & $0.69^{* *}$ & $0.28^{* *}$ & $0.67^{* *}$ & $0.42^{* *}$ & $0.54^{* *}$ & $0.47^{* *}$ & $0.71^{* *}$ & $0.64^{* *}$ \\
AI & $0.54^{* *}$ & $0.68^{* *}$ & $0.55^{* *}$ & 0.24 & $0.33^{* *}$ & $0.59^{* *}$ & 0.25 & 0.35 & 0.27 & 0.39 & $0.72^{* *}$ \\
\hline
\end{tabular}




\section{References}

1. United Nations. World Urbanization Prospects: The 2011 Revision; United Nations: New York, NY, USA, 2012.

2. Griffiths, P.; Hostert, P.; Gruebner, O.; van der Linden, S. Mapping megacity growth with multi-sensor data. Remote Sens. Environ. 2010, 114, 426-439. [CrossRef]

3. Kuang, W.; Chi, W.; Lu, D.; Dou, Y. A comparative analysis of megacity expansions in China and the U.S.: Patterns, rates and driving forces. Landsc. Urban Plan. 2014, 132, 121-135. [CrossRef]

4. Tsutsumida, N.; Saizen, I.; Matsuoka, M.; Ishii, R. Addressing urban expansion using feature-oriented spatial data in a peripheral area of Ulaanbaatar, Mongolia. Habitat Int. 2015, 47, 196-204. [CrossRef]

5. Haase, D.; Nuissl, H. Does urban sprawl drive changes in the water balance and policy? The case of Leipzig (Germany) 1870-2003. Landsc. Urban Plan. 2007, 80, 1-13. [CrossRef]

6. Inostroza, L.; Baur, R.; Csaplovics, E. Urban sprawl and fragmentation in Latin America: A dynamic quantification and characterization of spatial patterns. J. Environ. Manag. 2013, 115, 87-97. [CrossRef] [PubMed]

7. Wei, Y.; Zhang, Z. Assessing the fragmentation of construction land in urban areas: An indexmethod and case study in Shunde, China. Land Use Policy 2012, 29, 417-428. [CrossRef]

8. Musakwa, W.; van Niekerk, A. Implications of land use change for the sustainability of urban areas: A case study of Stellenbosch, South Africa. Cities 2013, 32, 143-156. [CrossRef]

9. Burton, E. The compact city: Just or just compact? A preliminary analysis. Urban Stud. 2000, 37, $1969-2001$. [CrossRef]

10. Jabareen, Y.R. Sustainable urban forms: Their typologies, models, and concepts. J. Plan. Educ. Res. 2006, 26, 38-52. [CrossRef]

11. Donnelly, S.; Evans, T.P. Characterizing spatial patterns of land ownership at the parcel level in south-central Indiana, 1928-1997. Landsc. Urban Plan. 2008, 84, 230-240. [CrossRef]

12. Niroula, G.S.; Thapa, G.B. Impacts and causes of land fragmentation, and lessons learned from land consolidation in South Asia. Land Use Policy 2005, 22, 358-372. [CrossRef]

13. Su, S.; Xiao, R.; Zhang, Y. Multi-scale analysis of spatially varying relationships between agricultural landscape patterns and urbanization using geographically weighted regression. Appl. Geogr. 2012, 32, 360-375. [CrossRef]

14. Su, S.; Hu, Y.; Luo, F.; Mai, G.; Wang, Y. Farmland fragmentation due to anthropogenic activity in rapidly developing region. Agric. Syst. 2014, 131, 87-93. [CrossRef]

15. Su, S.; Zhang, Q.; Zhang, Z.; Zhi, J.; Wu, J. Rural settlement expansion and paddy soil loss across an ex-urbanizing watershed in eastern coastal China during market transition. Reg. Environ. Chang. 2011, 11, 651-662. [CrossRef]

16. Tao, R.; Su, F.; Liu, M.; Cao, G. Land leasing and local public finance in China's regional development: Evidence from prefecture level cities. Urban Stud. 2010, 47, 2217-2236.

17. Huang, Z.; Wei, Y.D.; He, C.; Li, H. Urban land expansion under economic transition in China: A multilevel modeling analysis. Habitat Int. 2015, 47, 69-82. [CrossRef]

18. Long, H.; Zou, J.; Pykett, J.; Li, Y. Analysis of rural transformation development in China since the turn of the new millennium. Appl. Geogr. 2011, 31, 1094-1105. [CrossRef]

19. Seto, K.C.; Fragkias, M.; Guneralp, B.; Reilly, M.K. A meta-analysis of global urban land expansion. PLoS ONE 2011, 6, e23777. [CrossRef] [PubMed]

20. You, H. Quantifying megacity growth in response to economic transition: A case of Shanghai, China. Habitat Int. 2016, 53, 115-122. [CrossRef]

21. Li, X.; Zhou, W.; Ouyang, Z. Forty years of urban expansion in Beijing: What is the relative importance of physical, socioeconomic, and neighborhood factors? Appl. Geogr. 2013, 38, 1-10. [CrossRef]

22. Taubenböck, H.; Wiesner, M.; Felbier, A.; Marconcini, M.; Esch, T.; Dech, S. New dimensions of urban landscapes: The spatio-temporal evolution from a polynuclei area to a mega-region based on remote sensing data. Appl. Geogr. 2014, 47, 137-153. [CrossRef]

23. Time-series Landsat imageries. Available online: http://www.gscloud.cn/ (accessed on 1 March 2015).

24. Farina, A. Principles and Methods in Landscape Ecology; Chapman \& Hall: London, UK, 1998.

25. Su, S.; Wang, Y.; Luo, F.; Mai, G.; Pu, J. Peri-urban vegetated landscape pattern changes in relation to socioeconomic development. Ecol. Indic. 2014, 46, 477-486. [CrossRef] 
26. Tian, Y.; Jim, C.Y.; Tao, Y.; Shi, T. Landscape ecological assessment of green space fragmentation in Hong Kong. Urban For. Urban Green. 2011, 10, 79-86. [CrossRef]

27. Rempel, R. Patch Analyst 4. Computer Software Program Produced by the Author at Centre for Northern Forest Ecosystem Research, Lakehead University Campus. Available online: http:/ flash.lakeheadu.ca/ wrrempel/patch/download.htm (accessed on 6 April 2015).

28. Li, H.; Wei, Y.D.; Liao, F.H.; Huang, Z. Administrative hierarchy and urban land expansion in transitional China. Appl. Geogr. 2015, 56, 177-186. [CrossRef]

29. Wei, Y.D. Restructuring for growth in urban China: Transitional institutions, urban development, and spatial transformation. Habitat Int. 2012, 36, 396-405. [CrossRef]

30. Gao, J.; Wei, Y.D.; Chen, W.; Chen, J. Economic transition and urban land expansion in Provincial China. Habitat Int. 2014, 44, 461-473. [CrossRef]

31. Derudder, B.; Taylor, P.J.; Hoyler, M.; Ni, P.; Liu, X.; Zhao, M.; Shen, W.; Witlox, F. Measurement and interpretation of connectivity of Chinese cities in world city network, 2010. Chin. Geogr. Sci. 2013, 23, 261-273. [CrossRef]

32. Timberlake, M.; Wei, Y.D.; Ma, L.; Hao, J. Global cities with Chinese characteristics. Cities 2014, 41, $162-170$. [CrossRef]

33. Taylor, P.J.; Derudder, B.; Hoyler, M.; Ni, P.; Witlox, F. City-Dyad analyses of China's integration into the world city network. Urban Stud. 2014, 27, 868-882. [CrossRef]

34. Chen, J.; Chang, K.; Karacsonyi, D.; Zhang, X. Comparing urban land expansion and its driving factors in Shenzhen and Dongguan, China. Habitat Int. 2014, 43, 61-71. [CrossRef]

35. Ping, Y. Explaining land use change in a Guangdong county: The supply side of the story. China Q. 2011, 207, 626-648. [CrossRef]

36. Heikkinen, R.; Luoto, M.; Kuussaari, M.; Pöyry, J. New insights into butterfly-environment relationships using partitioning methods. Proc. R. Soc. B 2005, 272, 2203-2210. [CrossRef] [PubMed]

37. Porter, M.E. Location, competition, and economic development: Local clusters in a global economy. Econ. Dev. Q. 2000, 14, 15-34. [CrossRef]

38. Su, S.; Xiao, R.; Zhang, Y. Monitoring agricultural soil sealing in peri-urban areas using remote sensing. Photogramm. Eng. Remote Sens. 2014, 80, 367-372. [CrossRef]

39. Dietzel, C.; Herold, M.; Hemphill, J.J.; Clarke, K.C. Spatio-temporal dynamics in California's Central Valley: Empirical links to urban theory. Int. J.Geogr. Inf. Sci. 2005, 19, 175-195. [CrossRef]

40. Wu, J.; Jenerette, G.D.; Buyantuyev, A.; Redman, C.L. Quantifying spatiotemporal patterns of urbanization: The case of the two fastest growing metropolitan regions in the United States. Ecol. Complex. 2011, 8, 1-8. [CrossRef]

41. Su, S.; Li, D.; Hu, Y.; Xiao, R.; Zhang, Y. Spatially non-stationary response of ecosystem service value changesto urbanization in Shanghai, China. Ecol. Indic. 2014, 45, 332-339. [CrossRef]

42. Su, S.; Jiang, Z.; Zhang, Q.; Zhang, Y. Transformation of agricultural landscapes under rapid urbanization: A threat to sustainability in Hang-Jia-Hu region, China. Appl. Geogr. 2011, 31, 439-449. [CrossRef]

(c) 2015 by the author; licensee MDPI, Basel, Switzerland. This article is an open access article distributed under the terms and conditions of the Creative Commons by Attribution (CC-BY) license (http://creativecommons.org/licenses/by/4.0/). 